\title{
Tercer molar ectópico a nivel de región infraorbitaria-seno maxilar
}

\author{
Ectopic third molar of the maxillary sinus-infraorbital region
}

\author{
C. Moreno García', J. Collado López², F. Monje Gil3, H. Serrano Gil', A.J. Morillo Sánchez4,

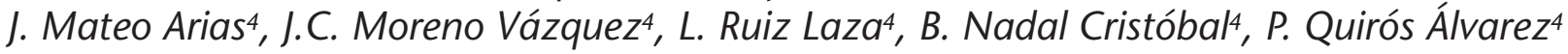

Resumen: Introducción. Los cordales ectópicos son aquellos incluidos en posiciones inusuales o desplazados a distancia de su normal localización anatómica. La erupción ectópica de un diente dentro de la cavidad oral es común pero en otros lugares es raro. La erupción ectópica puede ir asociada con alteraciones en el desarrollo, procesos patológicos o yatrogenia. Caso Clínico. Mujer de 56 años de edad con tercer molar superior derecho ectópico a nivel de región infraorbitaria-seno maxilar. Presentaba dolor e inflamación hemifacial derecha de larga evolución y resistente a tratamiento médico. Se realizó exéresis quirúrgica de dicho cordal mediante abordaje de Caldwell-Luc.

Discusión. En muchos casos la etiología de un cordal ectópico no puede ser identificada. La mayor parte de las veces son asintomáticos y diagnosticados mediante estudios radiológicos.

Conclusión. La indicación de la exodoncia en el caso de un diente ectópico en general viene determinada por la presencia de sintomatología o en prevención de futuras complicaciones.

Palabras clave: Cordal ectópico; Región infraorbitaria-seno maxilar; Caldwell-Luc.

Recibido: 20.04.06

Aceptado: 06.10 .06

\begin{abstract}
Introduction. Ectopic third molar teeth are those that are impacted in unusual positions, or that have been displaced and are at a distance from their normal anatomic location. Ectopic eruption of a tooth within the oral cavity is common, but rare in other sites. Ectopic eruption can be associated with developmental disturbances, pathologic processes or iatrogenic activity.

Case Report. Female, fifty-six years old, with an upper right ectopic third molar located in the maxillary sinus-infraorbital region. She presented with pain and inflammation of the right side of her face that she had been experiencing for along time and which had been resistant to treatment. Surgical excision was carried out of the third molar tooth using the Caldwell-Luc approach.

Discussion. In many cases the etiology of ectopic third molars cannot be identified. Generally they are asymptomatic and diagnosed by radiology studies.

Conclusion. The indication for extraction in ectopic teeth cases is in general determined by the presence of symptomatology, or by the need for preventing future complications.
\end{abstract}

Key words: Ectopic third molar tooth; Infraorbital region; CaldwellLuc.

\footnotetext{
1 Médico Residente de Cirugía Oral y Maxilofacial. Hospital Infanta Cristina. Badajoz.

2 Médico Residente de Cirugía Oral y Maxilofacial. Hospital Son Dureta. Palma de Mallorca.

3 Jefe de Servicio de Cirugía Oral y Maxilofacial.

4 Médico Adjunto de Cirugía Oral y Maxilofacial.

Hospital Infanta Cristina. Complejo Hospitalario Universitario de Badajoz, España.
}

\section{Correspondencia:}

Carlos Moreno García

c/ Jacinta García Hernández 7, Portal $25^{\circ} E$

06011 Badajoz, España.

Email: carlosmorenogarcia@wanadoo.es 


\section{Introducción}

El desarrollo de los dientes comienza con la migración de las células de la cresta neural hacia el maxilar y la mandíbula. Es un proceso continuo y actúa tanto el ectodermo de la cavidad bucal, responsable de la formación del esmalte, como el mesodermo del resto del diente. Algunas de las células mesenquimatosas de la cresta neural actúan sobre el ectodermo oral que las recubre, el cual se expresa en bandas en forma de " $U$ " (láminas dentarias) en el maxilar y la mandíbula. Esto ocurre hacia la sexta semana de vida intrauterina, siendo el primer indicio del desarrollo dental.

Una serie de complejas interacciones entre estos tejidos resultará en la formación del diente maduro. Un tejido anormal que interaccione durante el desarrollo puede potencialmente dar como resultado un diente ectópico. ${ }^{2,3}$

Al referirnos a cordales ectópicos hacemos mención a aquellos cordales incluídos en posiciones inusuales o desplazados a distancia de su normal localización anatómica (rama ascendente mandibular, cóndilo, apófisis coronoides, seno maxilar, región infraorbitaria, etc.). No se han establecido unos límites anatómicos para calificar un cordal incluído como ectópico. ${ }^{4}$

Un tercer molar puede estar desplazado a larga distancia de su ubicación habitual por un movimiento eruptivo abortado, por desplazamiento por una lesión como un quiste o tumoración o por bloqueo de su erupción por una lesión como por ejemplo un tumor odontogénico.

La erupción ectópica de un diente dentro de la cavidad oral es común pero en otros lugares es raro. Los dientes ectópicos a nivel del seno maxilar- región infraorbitaria son una entidad poco frecuente. La erupción ectópica puede estar asociada con alteraciones en el desarrollo, procesos patológicos o yatrogenia. La etiología de un diente ectópico no es siempre conocida. ${ }^{2}$

\section{Caso clínico}

Mujer de 56 años de edad, sin antecedentes personales de interés, que acude a consultas de Cirugía Oral y Maxilofacial del Hospital Infanta Cristina de Badajoz, derivada por su Médico de Familia. La paciente presenta sensación de tensión hemifacial derecha y dolor a la palpación de dicha región. Refiere episodios de dolorinflamación que cedieron tras el tratamiento con antibióticos y antiinflamatorios. Describe el cuadro como de años de evolución así como una discreta asimetría facial que ha ido evolucionando progresivamente hasta hacerse más patente en los últimos meses. En la exploración física se aprecia abombamiento de vestíbulo superior derecho, doloroso a la palpación.

Se solicitó una ortopantomografía (Fig. 1) así como una TAC facial (Figs. 2 y 3 ) apreciándose en ambas un tercer molar (18) inclui- shaped bands (dental lamina) in the maxilla and mandible. This occurs towards the sixth week of intrauterine life, with this being the first indication of dental development. ${ }^{?}$

A complex series of interactions between these tissues will result in the formation of a mature tooth. Abnormal tissue that interacts during development could potentially result in an ectopic tooth. 2,3

On referring to ectopic third molar teeth, we refer to those that are impacted in unusual positions, or those that are displaced and that are at a distance from their normal anatomic site (ascending mandibular ramus, condyle, coronoid apophysis, maxillary sinus-infraorbital region, etc.). No anatomic boundaries have been established for defining an impacted third molar tooth as ectopic. ${ }^{4}$

A third molar can be displaced a great distance from its habitual location because of an aborted eruption, because of displacement of a lesion due to a cyst or tumor-like mass, or because its eruption was blocked because of an odontogenic type tumor lesion.

The ectopic eruption of a tooth within the oral cavity is common, but in other areas this is rare. An ectopic tooth by the infraorbital maxillary sinus region is a rare entity. Ectopic eruption can be associated with developmental disturbances, pathologic processes or iatrogenic activity. The etiology of an ectopic tooth is not always known.?

\section{Case Report}

Female, 56 years old, with no medical history of interest, was referred to the department of Oral and Maxillofacial Surgery of the Hospital Infanta Cristina, Badajoz, by her general practitioner. The patient presented with a sensation of tension on the right half of her face that was painful on palpation. She reported episodes of pain and inflammation that remitted with antibiotic and anti-inflammatory treatment. She had experienced these symptoms for many years together with slight facial asymmetry that was slowly pro- 
do a nivel del techo del seno maxilar derecho - región infraorbitaria derecha.

Dada la sintomatología clínica de la paciente se optó por realizar tratamiento quirúrgico mediante abordaje de Caldwell-Luc. ${ }^{13-21}$ Bajo anestesia general e intubación oro-traqueal se realizó incisión de Neumann a nivel de vestíbulo superior derecho. Tras elevación de colgajo mucoperióstico se visualizó la cápsula quística y la cortical maxilar de aspecto papiráceo con adherencias y fibrosis. Posteriormente se procedió a la exéresis de la cavidad quística y exodoncia del cordal mediante el uso de fórceps. Finalmente se realizó legrado intenso de la cavidad y sutura del colgajo mediante material reabsorbible (Figs. 4 Y 6).

El estudio anatomopatológico fue informado como compatible con quiste radicular.

\section{Discusión}

La etiología de la erupción ectópica no está todavía del todo clara y muchas teorías han sido propuestas incluyendo, traumatismos, infección, quistes, tumores y alteraciones del desarrollo.2-4,11 En muchos casos la etiología no puede ser identificada. ${ }^{3}$ En ocasiones el diente puede migrar a distintas localizaciones, incluyendo el seno maxilar - región infraorbitaria. 2,3,8,9,25-28

La impactación de un diente en el seno maxilar-región infraorbitaria puede ser asintomática. En algunos casos los pacientes experimentan síntomas en relación con sinusitis como cefalea, obstrucción nasal, inflamación facial, etc. ${ }^{7,12,22}$

La mayor parte de las veces son asintomáticos y diagnosticados mediante estudios radiológicos, que deben incluir radiografías intrabucales, ortopantomografía así como TC. 4,23,24

La indicación de la exodoncia en el caso de un diente ectópico en general viene determinada por la presencia de sintomatología o en prevención de futuras complicaciones. En el caso de optar por tratamiento conservador será necesario el seguimiento del paciente. ${ }^{4,5}$

Siempre que sea posible deberán emplearse abordajes intraorales, pero lógicamente ello vendrá determinado por la localización del cordal. ${ }^{4}$

El tratamiento de un diente ectópico a nivel del seno maxilarregión infraorbitaria consiste en le exéresis quirúrgica. Presentamos
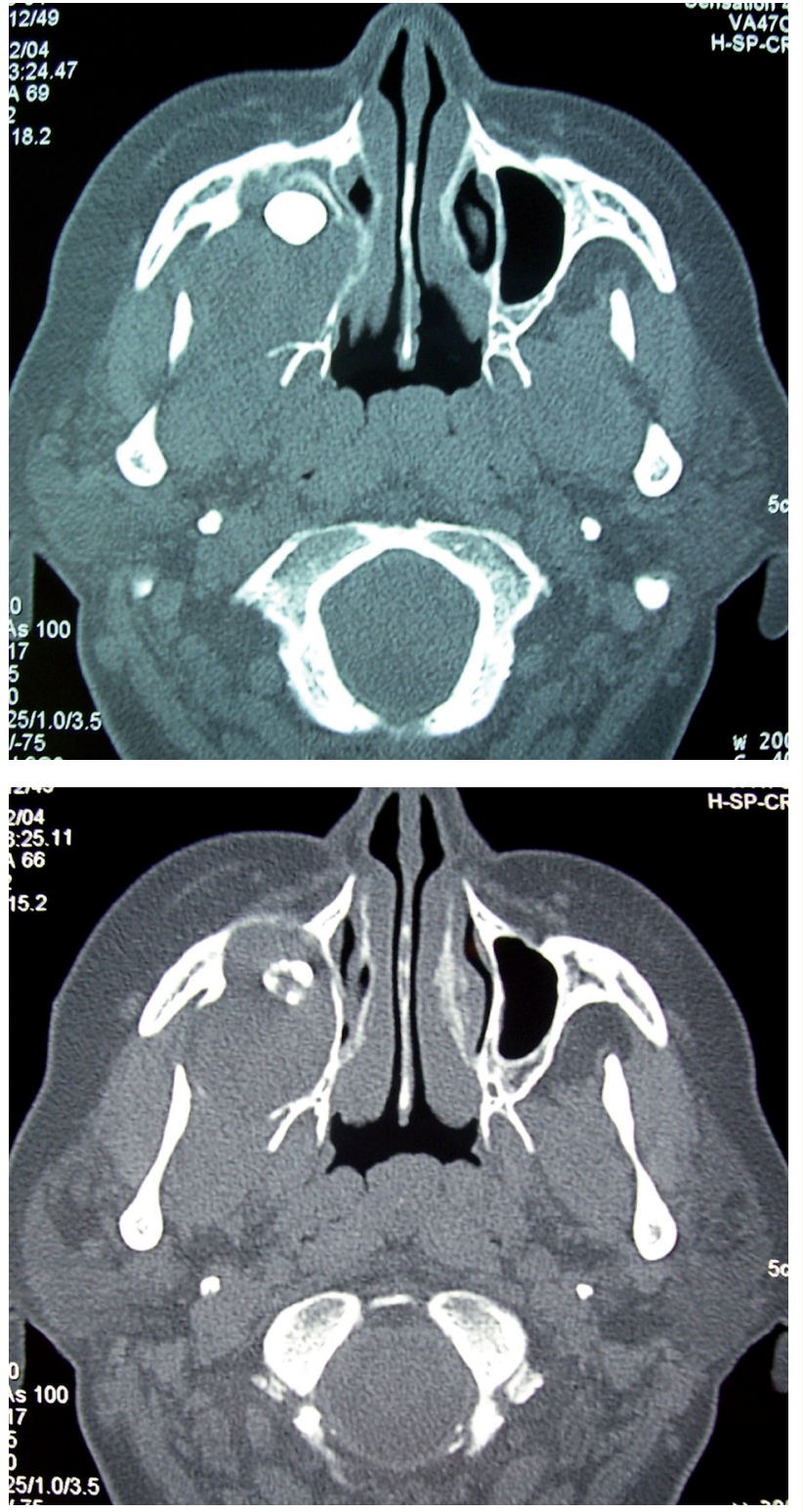

FiguraS 2 y 3 . Corte axial de TC en el que observamos el cordal superior derecho localizado en región infraorbitaria-seno maxilar. Figures 2 and 3. Axial slice with CT scan showing upper right third molar tooth located in the maxillary sinus-infraorbital region. gressive, and which had been more obvious over recent months. Her physical examination revealed bulging of the upper right vestibule that was tender to palpation.

An orthopantomography was requested (Fig. 1) together with a facial CAT scan (Figs. 2-3) which both revealed a third molar (18) that was impacted in the roof of the maxillary sinus, right infraorbital region.

Given the clinical symptoms of the patient, surgical treatment using the Caldwell-Luc approach was decided on. ${ }^{13-21}$ Under general anesthesia and following oro-tracheal intubation, a Neumann incision was made in the upper right vestibule. After raising a mucoperiosteal flap, a cystic capsule was observed. The maxillary cortex had a papery appearance, and adherences and fibrosis could be observed. The cystic cavity was then excised and the third molar tooth was removed with forceps. Finally, intense curettage was carried out of the oral cavity and the flap was sutured with resorbable material (Figs. 4-6).

The anatomopathologic report was compatible with a radicular cyst.

\section{Discussion}

The etiology of an ectopic eruption is still not clear and many theories have been put forward including, trauma, infection, cysts, tumors and developmental disturbances. ${ }^{2-}$ 4,11 In many cases the etiology cannot be identified. ${ }^{3}$ On occasions the tooth can migrate to a distant site including the maxillary sinus-infraorbital region. 2,3,8,9,25-28

A tooth impacting in the maxillary sinus-infraorbital region can be asymptomatic. In some cases the patients 
un caso de un tercer molar ectópico a dicho nivel y que fue extraído mediante el procedimiento de Caldwell-Luc.

\section{Conclusión}

El tratamiento de un diente ectópico en el seno maxilar-región infraorbitaria viene determinado por la presencia de sintomatología o en prevención de futuras complicaciones. Usualmente la técnica más utilizada es la intervención de Caldwell-Luc. Este abordaje ofrece un excelente acceso para extraer la pieza dentaria y el material patológico adyacente. En el caso de que se decidiese una actitud conservadora, será necesario un control periódico del paciente. ${ }^{2}$

\section{Bibliografía}

1. Simón Sanz $\mathrm{M}^{\circ}$. Odontogénesis y Erupción dentaria. Manual de Cirugía Oral y Maxilofacial. Ed GlaxoSmithKline 2004;3:43-6.

2. Cemil Büykkurt N, Sinan T, Hamdi Aras M, Ümit $\mathrm{Y}$. Ectopic eruption of a maxillary third molar tooth in the maxillary sinus: A case report. J Contempor Dental Pract 2005;6.

3. Chye C, Singh B. Rapid cystic development in relation with an impacted lower third molar: A case report. Ann Acad Med Singapore 2005;34: 130-3.

4. Infante Cossío P, Gutiérrez Pérez JL. Situaciones especiales en la exodoncia de cordales incluidos. El tercer molar incluido. Ed. GlaxoSmithKline. 2001;10:184-92.

5. Chiapasco M, Cassenti P, Garantini G, Meazzini M. Dientes incluidos. Cirugía Oral. Ed. Masson 2004;5:119-72.

6. Donado Rodríguez M. Dientes incluidos. Cirugía Bucal, Patología y Técnica. Ed. Masson 2004;22:345-65.

7. Goh YH. Ectopic eruption of maxillary molar tooth, an inusual cause of recurrent sinusitis. Singapore Med I 2001;42:80-1.

8. Elango S, Palaniappan SP. Ectopic tooth in the roof of the maxillary sinus. Ear Nose Throat J 1991;70:365-6.

9. Bodner L, Tovi F, Bar-Ziv J. Teeth in the maxillary sinus, imaging and management. J Laryngol Otol 1997; 111:820-4.

10. Alling RD, Alling III CC. Removal of impacted teeth and lesions from inusual locations. Oral Maxillofac Surg Clin North Am 1993;5:111-19.

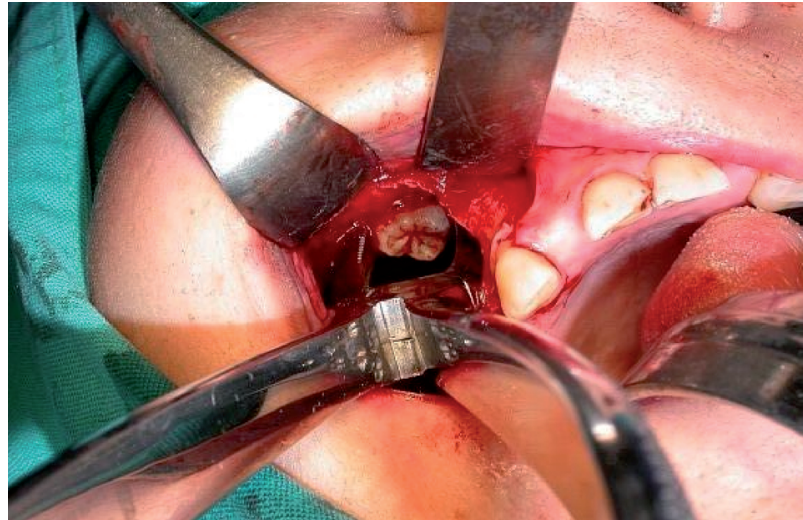

Figura 4. Exodoncia mediante fórceps del cordal ectópico a nivel de región infraorbitaria-seno maxilar (Abordaje de Caldwell-Luc). Figure 4. Extraction with forceps of ectopic third molar tooth in maxillary sinus-infraorbital region (Caldwell-Luc approach).

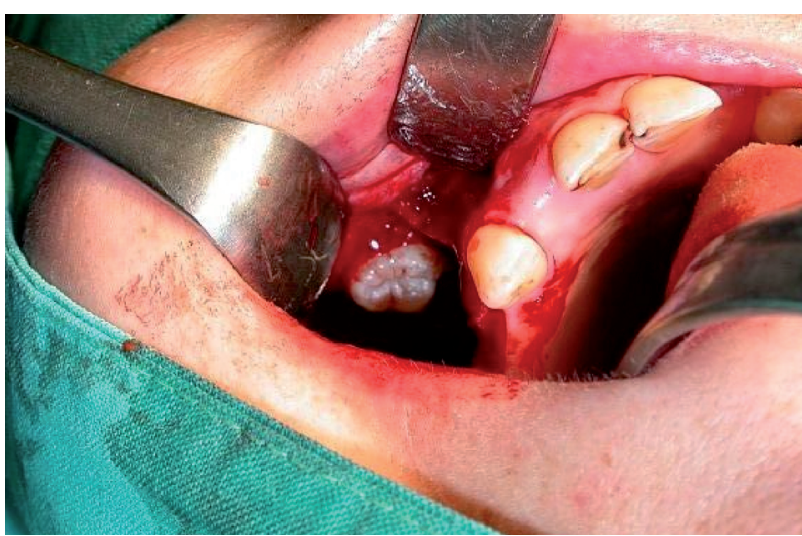

Figura 5. Observamos el cordal a nivel del techo del seno maxilar-región infraorbitaria (Abordaje de Caldwell-Luc).

Figure 5. The third molar tooth can be observed by the maxillary sinus roof, infraorbital region (Caldwell-Luc approach).

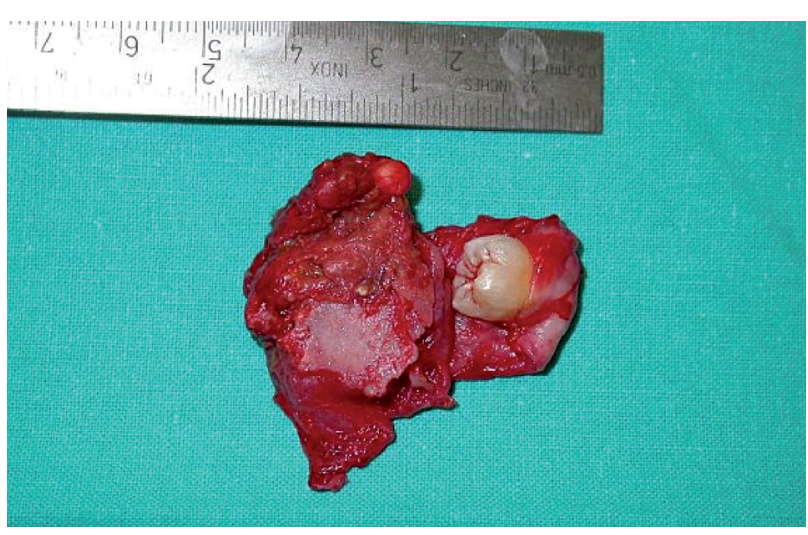

Figura 6. Pieza operatoria que incluye el cordal ectópico, la lesión quística asociada y mucosa del seno maxilar.

Figure 6. Operative specimen including the ectopic third molar tooth, associated cystic lesion and mucosa of the maxillary sinus. experience sinusitis-related symptoms such as headaches, nasal obstruction, facial inflammation, etc. 7,12,22 Patients are mostly asymptomatic and diagnosed by means of radiology studies that may include intra-buccal radiographies, orthopantomographies as well as CAT scans. $4,23,24$

The indication for the extraction of an ectopic tooth is in general determined by the presence of symptomatology, or it may be aimed at preventing future complications. If conservative treatment is opted for, a follow-up of the patient will not be necessary. ${ }^{4,5}$

Whenever possible intraoral approaches should be used but logically this will be determined by the location of the third molar tooth. ${ }^{4}$ Treating an ectopic tooth in the maxillary sinusinfraorbital region, entails surgical excision. The case is presented of an ectopic third molar in this area that was extracted using the Caldwell-Luc procedure.

\section{Conclusion}

Treatment for an ectopic tooth in the maxillary sinusinfraorbital region, is determined by the presence of symptomatology, or it may be aimed at preventing future complications. Usually the most used technique is the Caldwell-Luc approach. This approach provides excellent access for extracting the tooth and the adjacent pathological material. If a conservative approach is decided on, periodic monitoring of the patient will be necessary. ${ }^{2}$ 
11. Lyttle JJ. Etiology and indication for the management of impacted teeth. Oral MaxillofacSurg Clin North Am 1993;5:63-75.

12. Williams PE. Enfermedades del seno maxilar de origen dentario. Cirugía Buco-Maxilofacial de GO Kruger. Ed. Panamericana, Buenos Aires: 1986;254-67.

13. Barzilai G, Greenberg E, Uri N. Indications for the Caldwell-Luc approach in the endoscopic era. Otolaryngol Head Neck Surg 2005; 132:219-20.

14. Al-Belasy FA. Inferior meatal antrostomy: is it necessary after radical sinus surgery through the Caldwell-Luc approach? J Oral Maxillofac Surg 2004;62:559-62.

15. Matheny KE, Duncavage JA. Contemporary indications for the CaldwellLuc procedure. Curr Opin Otolaryngol Head Neck Surg 2003;11:23-6.

16. Tang XH, Wang LH, Shi JB. Treatment of patients with chronic sinusitis by endoscopic and Caldwell-Luc approaches. Lin Chuang Er Bi Yan Hou Ke Za Zhi 2000; 14:503-4.

17. Romagnoli R, Aimetti M, Secco F, Brucoli M. The Caldwell-Luc procedure in the management of maxillary sinusitis. Long term results. Minerva Stomatol 1998; 47:143-7.

18. Ferekidis E, Tzounakos P, Kandiloros D, Kaberos A, Adamopoulos G.Modifications ofthe Caldwell-Luc procedure for the pervention of post-operative sensitivity disorders. J Laryngol Otol 1996;110:228-31.

19. Low WK. Complications of the Caldwell-Luc operation and how to avoid them. Aust N Z J Surg 1995;65:582-4.
20. Saito H, Takanami N, Saito T, Wakui S, Fujieda S. Studies on the Caldwell-Luc operation with or without counteropening at the inferior meatus. ORL J Otorhinolaryngol Relat Spec 1990,52:249-53.

21. De Freitas J, Lucente FE. The Caldwell-Luc procedure: institutional review of 670 cases: 1975-1985. Laryngoscope 1998;98:1297-300.

22. Bertrand B, Roumbax P, Eloy P, Reychler H. Sinusitis of dental origin. Acta Otorhinlaryngol Belg 1997;51:315-22.

23. Bouquet A, Coudert JL, Bourgeois D, Mazoyer JF, Bossard D. Contributions of reformatted computed tomography and panoramic radiography in the localization of third molars relative to the maxillary sinus. Oral Surg Oral Med Oral Pathol Oral Radiol Endod 2004;98:342-7.

24. Brown RS, Coleman-Bennett M, Abramovitch K. Panoramic radiographic findings: case reports of ectopic teeth and antroliths within or adjacent to the maxillary sinus. Dent Today 2002;21:50-3.

25. Erasmus JH, Morkel JA. Ectopic antral teeth: diagnosis and management implications. SADJ 2005;60:66-8.

26. Gunbay MU. Lomcali G, Ozaksoy D, Sutay S, Altunay C. Ectopic teeth in the maxillary sinus: diagnosis and treatment. Dent Update 1995; 22:146-8.

27. Hook PC. Ectopic third molar in maxillary sinus. Aust Dent / 1995;40: 339.

28. Di Felice R, Lombardi T. Ectopic third molar in the maxillary sinus. Case report. Aust Dent / 1995;40:236-7. 